\title{
Women, engineering and gender equality: Brazil and United States pathway
}

\author{
Mulheres, engenharia e equidade de gênero: \\ trajetória brasileira e norte-americana
}

\author{
Chiquita Howard-Bostic ${ }^{1}$ \\ Denise Almeida de Andrade ${ }^{2}$ \\ Monica Sapucaia Machado ${ }^{3}$
}

\begin{abstract}
The task of discussing gender equity in society remains challenging, and new systemic strategies are needed to increase women's participation in leading professions. Two decades after the 21st century, inequality between men and women continues to produce detrimental effects that reproduce past discriminatory behaviors and actions. We argue that
\end{abstract}

1 Associate Vice President of the Diversity, Equity and Inclusivity Chair at the Department of Sociology, Criminology and Criminal Justice. Associate Professor of Sociology at Shepherd University in Shepherdstown, West Virginia (US). ORCID: https://orcid.org/0000-0002-9314-8957

2 Ph.D. and master's degree in Constitutional Law. Permanent professor at Centro Universitário Christus - UNICHRISTUS - Ceará, Brazil. Author of the book Family Planning: gender equality and coparenting. ORCID: http://orcid.org/0000-0003-3243-480X

3 Ph.D. and master's degree in political and economic law. Permanent professor in the Brazilian Institute of Education, Development, and Research - IDP in Brasília and São Paulo, Brazil. Author of the book Women's Law: Higher Education, Labor, and Autonomy. ORCID: https:// orcid.org/0000-0003-1473-1042 
professional training, financial support, economic autonomy, and structural adjustments are essential for women to overcome barriers of gender equity. Likewise, realizing that countries have expressly indicated that technology, engineering, and innovation are essential to development, we intend to focus our attention to the male domination in the field of engineering. We will analyze women's enrollment in engineering courses in Brazil to explain why men are a demographic majority in the profession. Given this international reality, we also plan to show how access to the knowledge areas of engineering and disparities in the study of engineering is also relevant in the United States. This study finds that the knowledge gap begins with differential socialization and development of girls and boys, who are presented with stereotypes that permeate and influence their perceptions, professional choices, and performance in the workplace. Fewer girls than boys choose engineering as a field and after the first 20 years of service, greater than $30 \%$ of women have not remained in the engineering field. Even when women are technically prepared, they may experience stereotype threat, which can adversely impact their performance in the field.

Keywords: Equality. Women. Technology. Women Engineering.

Resumo: A tarefa de discutir igualdade de gênero remanesce desafiadora e novas estratégias são necessárias para garantir o incremento da participação das mulheres em profissões de relevância para a sociedade. Ao final da segunda década do século XXI, a desigualdade entre homens e mulheres continua a produzir efeitos que reproduzem comportamentos e ações historicamente discriminatórios. Discutiremos a importância da formação profissional, do apoio fi- 
nanceiro, da autonomia econômica e da realização de mudanças estruturais para que se consiga superar as barreiras criadas pela discriminação de gênero. Aliado a isso, intentamos analisar o domínio masculino da engenharia, sob a perspectiva de que os Estados expressamente afirmam que tecnologia, engenharia e inovação são essenciais ao desenvolvimento. Analisaremos a presença das mulheres nos cursos de engenharia no Brasil buscando compreender o porquê desta maioria masculina, bem como, reconhecendo ser um cenário não exclusivo do Brasil, demonstraremos que o acesso e as disparidades no campo da engenharia também afetam países desenvolvidos, como os Estados Unidos. Concluimos que esse abismo encontra sua origem numa diferenciação social entre masculino e feminino, que afeta o desenvolvimento de meninas e meninos, os quais se deparam com estereótipos que influenciam e condicionam suas percepções e seu desempenho professional. Um número menor de meninas escolhe o campo da engenharia; após 20 anos de profissão mais de $30 \%$ das mulheres engenheiras desistem da carreira; e mesmo quando escolhem esse campo de trabalho e são tecnicamente preparadas podem sofrer as consequências da chamada 'ameaça do estereótipo", que as impõe uma percepção de subalternidade e pode impactar negativamente em seu desempenho profissional.

Palavras-chave: Igualdade. Mulheres. Tecnologia. Mulheres na engenharia.

\section{Opening thoughts}

Brazil and the United States have many similarities but the countries are structurally different. Despite being federations and products of European colonization, the political 
and economic histories have culminated distinct social realities and have distanced considerably since the beginning of the 20th century. With regard to higher education, private universities have the highest enrollment in both countries. Differences in higher education are fundamental. The United States became an exponent of modern technological capitalism whereas Brazil remained centrally agricultural with late industrialization that was led by the State. Despite these differences, barriers imposed on women in technological areas have proximity. In both countries, women occupy limited power and decision making in engineering fields.

In Brazil, public universities exist in all Brazilian states and are financed by the government. The Brazilian government is also primarily responsible for training highperformance professionals and scientists. In the United States, students are responsible for their college tuitions. Private universities are financed using student resources or through loans, which they must qualify for. Brazil has only two types of universities, paid private and free public. Brazilian technological production occurs centrally in public universities, and is fully supported by the government. While the United States offers grants and scholarships, it does not have a completely free institution; students pay a tuition at public colleges and universities. Therefore, most of the scientific production carried out at the Brazilian University belongs to the researcher and the Brazilian state. In contrast, the scientific production carried out at American universities belong to the researcher and the financier, which may be considered as public or private goods and services. The comparison raised here concerns gender inequalities in technological and prestigious careers as engineering. We propose to debate the challenges aligned with women's entry and presence in engineering careers. Our starting point 
for analysis is a comparison of Brazilian and American women's participation in engineering fields. In Brazil, the first woman to graduate from a higher education institution was Rita Lobato Velho Lopes in 1887. In 1928, the first female engineer graduated from the São Paulo polytechnic school, and the second graduated almost 20 years later in 1945 (MACHADO, 2019, p. 68). In the United States in 1876, Elizabeth Bragg was the first woman to graduate, from the University of Berkeley, California as an engineer (LAYNE, 2009). While women in the United States were already earning engineering degrees, it was illegal for women to attend Brazilian colleges, Engineering remains masculine in both power and numbers.

Today in Brazil, women make up the majority population of university students, including professions that had once been considered male dominated professions such as legal and medical fields. Nevertheless, in engineering fields, women are still a minority population, accounting for slightly more than $20 \%$ of students (LOMBARDI; GONZALES, 2016, p. 172) and 15\% (CONFEA) of engineers, and women are practically nonexistent in more prominent engineering areas. Data shows minimal increases in female enrollment in the Academy in Brazil.

In the United States, more women than men have completed four-year college degree programs. For instance, in 2019 , "36.6\% of all women over age 25 had a bachelor's degree as compared to $35.4 \%$ of men" (STATISTA, online). In contrast, women have earned $21 \%$ of all bachelor's degrees in engineering fields and make up 13\% of all engineers (SWE, online). Although American women began earning degrees 52 years before Brazilian women, both countries still have low gender equality rates in the engineering field. 


\section{The last frontier or the impassable frontier: a look at engineering}

The imperial professions, law, medicine, and engineering were the initial field of study in higher education in Brazil. The title imperial was assigned because of the social and exchange value of these professions. As well, the professions require a college degree and do not involve manual labor or repetitive work. .. Liberal professions developed from imperial professions and fields, as Coelho (1999, p. 24) explains are: "Specialized activity that requires preparation through formal higher education training, have social or intellectual prestige or both". The liberal professions are practiced autonomously and have a knowledge base that is predominantly technical or intellectual.

Imperial professions were paths for the sons of wealthy individuals. As offspring of the rich relocated to urban centers, engineering professions emerged as the urban middleclass path. The urban elite has recently become the center of Brazilian capital. However, agribusiness was and still is Brazil's economy base; since imperial college professions were initiated, students were male children of the landowners and civil servants.

Since engineering remains as a male majority profession, it is essential to explore the presence or absence of unspoken barriers that have originated from patriarchy, which oversees maintaining social roles established for men and women. In 2006, Maria Rosa Lombardi (2006c, p. 113) pointed out that:

[...] throughout the decade of [19] 90 and in the first years of the new millennium, the number of women who entered Engineering courses in Brazil grew slowly and continuously. [...] in 1991, the female share in the set of enrollments in Engineering courses was 
$16.4 \%$, it grew to $19.5 \%$ in 1995 , data showed a slight decrease in the following years, and enrollments reached $20 \%$ in 2002.

Lombardi referenced socio-cultural difficulties that Engineering students were subjected to and explained how these difficulties did not progress substantially under the male domain: "the minority group of women is still the target of stigmatization by the male majority group" (LOMBARDI, 2006c, p. 129). Prejudices towards women are still echoed and cause strangeness in the Engineering classrooms.

The number of female faculty member in the engineering field is low as well. In the Civil Engineering department at the University of São Paulo (USP), five of 31 faculty members in the department of the Polytechnic School, were women in 2018 (POLITÉCNICA, [s.d.]); in the Department of Energy Engineering and Electrical Automation, there were 37 faculty, only three of whom were women. (DEPARTAMENTO DE ENGENHARIA DE ENERGIA E AUTOMAÇÃO ELÉTRICAS, [s.d.]). Since 1955, the school granted 26 emeritus titles, and the last two occurred in 2013. No women have received the honor.

Regarding directors positions, between 1893 and 2017, no woman had occupied the chair position (ESCOLA POLITÉCNICA, [s.d.]). In 2018, Professor Liedi Legi Bariani Bernucci from the Department of Transport Engineering was the first woman to manage the school's board. During his tenure in the administration, only 21 women of the 153 members of the Congregation were responsible for all significant academic, administrative, and financial aspects Among these female leaders, there were no department heads (ESCOLA POLITÉCNICA, [s.d.]).

The field of engineering has been masculine, especially the presence and occupation of functions with decisionmaking power. The Federal Council of Engineering and 
Agronomy (CONFEA) stated that, in 2018, among the Engineering and Agronomy professionals registered in Brazil, only $14 \%$ were women (see Table 1 ).

\section{Table 1 - Professionals in Engineering and Agro- nomy enrolled in Regional Councils by the State of the Federation, Year, and Sex 4 .}

\begin{tabular}{|c|c|c|}
\hline CREA & Masculine & Feminine \\
\hline CREA-AC & $77,84 \%$ & $22,16 \%$ \\
\hline CREA-AL & $87,03 \%$ & $12,97 \%$ \\
\hline CREA-AM & $78,98 \%$ & $21,02 \%$ \\
\hline CREA-AP & $85,13 \%$ & $14,87 \%$ \\
\hline CREA-BA & $84,55 \%$ & $15,45 \%$ \\
\hline CREA-CE & $86,06 \%$ & $13,94 \%$ \\
\hline CREA-DF & $85,84 \%$ & $14,16 \%$ \\
\hline CREA-ES & $85,23 \%$ & $14,77 \%$ \\
\hline CREA-GO & $83,66 \%$ & $16,34 \%$ \\
\hline CREA-MA & $82,63 \%$ & $17,37 \%$ \\
\hline CREA-MG & $84,88 \%$ & $15,12 \%$ \\
\hline CREA-MS & $85,14 \%$ & $14,86 \%$ \\
\hline CREA-MT & $82,12 \%$ & $17,88 \%$ \\
\hline CREA-PA & $79,24 \%$ & $20,76 \%$ \\
\hline CREA-PB & $84,04 \%$ & $15,96 \%$ \\
\hline CREA-PE & $83,66 \%$ & $16,34 \%$ \\
\hline CREA-PI & $86,95 \%$ & $13,05 \%$ \\
\hline CREA-PR & $85,55 \%$ & $14,45 \%$ \\
\hline CREA-RJ & $87,86 \%$ & $12,14 \%$ \\
\hline CREA-RN & $83,05 \%$ & $16,95 \%$ \\
\hline CREA-RO & $80,50 \%$ & $19,50 \%$ \\
\hline CREA-RR & $71,67 \%$ & $28,33 \%$ \\
\hline & & \\
\hline
\end{tabular}

4 SOURCE: Own elaboration based on data from CONFEA, [s.d]. 


\begin{tabular}{|c|l|l|}
\hline CREA-RS & $86,30 \%$ & $13,70 \%$ \\
\hline CREA-SC & $84,78 \%$ & $15,22 \%$ \\
\hline CREA-SE & $83,98 \%$ & $16,02 \%$ \\
\hline CREA-SP & $88,29 \%$ & $11,71 \%$ \\
\hline CREA-TO & $80,34 \%$ & $19,66 \%$ \\
\hline TOTAL: & $85,92 \%$ & $14,08 \%$ \\
\hline
\end{tabular}

Regarding the figures in the table above, it is worth noting that percentages are similar in all states of the federation. States with more than 100,000 engineers included Minas Gerais (15\%), Rio de Janeiro (12\%), and São Paulo (11\%). The 2017 student guide (E-GUIA DO ESTUDANTE, [s.d.]) listed 34 specialized engineering fields ranging from Acoustic Engineering to Textile Engineering. Despite the variety of specialized areas, civil, mechanical, electronical, and production engineering have the largest number of professionals, as shown in the table below.

\section{Table 2 - Total engineers in typical occupations by category ${ }^{5}$.}

\begin{tabular}{|cll|}
\hline Família CBO & \multicolumn{1}{c|}{ Description } & Total workers \\
\hline 2021 & Mechatronic Engineers & $\mathbf{3 0 2}$ \\
\hline 2122 & Computer Engineers & $\mathbf{3 . 5 1 0}$ \\
\hline 2140 & Environmental Engineers & $\mathbf{1 2 3}$ \\
\hline 2142 & Civil Engineers & $\mathbf{7 2 . 1 5 8}$ \\
\hline 2143 & Electrical and Electronics Engineers & $\mathbf{3 3 . 8 7 0}$ \\
\hline 2144 & Mechanical Engineers & $\mathbf{3 0 . 0 8 0}$ \\
\hline
\end{tabular}

5 SOURCE: Rais Data (Brasil, 2011 apud SOUZA; DOMINGUES, 2014, p. 380). 


\begin{tabular}{|cll|}
\hline 2145 & Chemical Engineers & $\mathbf{1 1 . 9 5 4}$ \\
\hline 2146 & Metallurgical and Material Engineers & $\mathbf{3 . 5 4 1}$ \\
\hline 2147 & Mine Engineers & $\mathbf{3 . 3 3 0}$ \\
\hline 2148 & Surveyor Engineers & $\mathbf{9 0 7}$ \\
\hline 2149 & $\begin{array}{l}\text { Production, Quality and Security En- } \\
\text { gineers }\end{array}$ & $\mathbf{3 1 . 7 8 3}$ \\
\hline 2221 & Engenheiros agrossilvipecuários & $\mathbf{2 1 . 3 4 7}$ \\
\hline 2222 & Food Engineers & $\mathbf{2 9}$ \\
\hline- & $\begin{array}{l}\text { Total engineers in typical occupa- } \\
\text { tions }\end{array}$ & $\mathbf{2 1 2 . 9 3 4}$ \\
\hline
\end{tabular}

Lombardi (2005, p. 17) describes women's involvement in civil engineering, the most pursued specialization in the field:

[...] since 1960, in Brazil, the highest proportions of women who graduated in Engineering courses came from the civil specialty $(65 \%)$. This area also brought together the majority of male graduates that year. Civil engineering was the first course offered in Brazil.

Even considering a more significant presence of women in civil engineering, statistical findings in the Brazilian Census of Higher Education in 2015 ranked engineering as four of ten highly enrolled courses by men; civil engineering was ranked third for male enrollment (MINISTÉRIO DA EDUCAÇÃO; INEP, 2015, on line).

Since the entry of women into the workplace has still been minimal among female faculty, engineering is still a stronghold and increases in hiring will take time. According to Lombardi (2005, p. 137), when pondering choice of professions during their interviews, women chose to study engineering as an instrument of confrontation: 
The reports show a peculiarity of patterns of "tantrums" displayed by women. That is to say, when choosing this profession, women have been opposed to the expectations and desires of family members and society in general; they have been resistant to a gender ideology that has signaled (and still signals) professional fields that are suitable for women. This resistance via a "tantrum" was present in reports of older and younger women, suggesting the permanence of gender patterns and images linked to profession' choices in the last thirty years in Brazil.

Prior knowledge in mathematics play a dominant role regarding study success in engineering careers. When women's enrollment increased in higher education, interests in medicine and law also increased considerably. Both fields experienced growth in female participation. Basic mathematical knowledge in algebra, trigonometry, and physics also tend to be the most challenging for students. Mathematical education and knowledge are very political given its research domain, which inherently entails rigor and a special nature of learning and teaching. The historical implications for privilege and power also link to the identities of researchers who carry out mathematic studies in related areas. These studies have continued to offer so little in the way of progress for students who remain the most underserved such as women, poor students, and minority ethnic populations. As University of Macau professors recall: “Napoleon invoked mathematics to legitimize power relations by stating, 'men are like figures; they are only valuable for their position'" (OLIVEIRA; NEGREIROS; NEVES, p. 1025). Women's access to mathematical learning in the history of humankind and consequently in Brazil, has been restricted and even prohibited at particular historical moments. It is worth noting that teachers were instructed not to teach geometry, a subject that determined salary increases and career progression, when they entered the public service in Brazil (BRUSCHINI; AMADO, 1988). 
Even when Brazilian women enter engineering and related mathematical field, salaries are not equitable. The "difficult relationship" between women's salaries and mathematics is not only a Brazilian issue, but performance of girls in the study of mathematics is inferior in most countries. In 2003, the PISA - Program of International Student Assessment under the coordination of the Organization for Economic Co-operation and Development - OEDC conducted a survey in 41 countries, including Brazil, and found that boys still have more significant incomes than girls everywhere (ANDRADE; FRANCO; CARVALHO, 2003, p. 79).

Studying mathematics and related knowledge areas is still seen as masculine even though the number of women in in the filed as increased gradually. In a study carried out in 2009 by Charles and Bradley from the Universities of California and Western Washington, with 44 countries, they pointed out that discourse at school, among families, and in society about opportunities for girls and boys center career choice, confidence of girls, and learning and teaching commitments of teachers.

Because gender remains so central an axis of human identity, we argue that self-expressive value systems tend to encourage the development and enactment of culturally masculine or feminine affinities. Girls may, for example, be more likely to express an aversion to mathematics and avoid related programs where self-expression is a legitimate, and even normative, criterion for curricular choice. Structural features of modern educational systems and labor markets may also promote gender-differentiated aspirations and their realization (CHARLES; BRADLEY, 2009, p. 926).

In Brazil, despite being the majority among competitors, the National High School Examination (ENEM) of 2018 shows that girls do not have great results, and in mathematics the score difference between boys and girls is more pronounced. 
More than $70 \%$ of the students who obtained the thousand highest marks in the National High School Exam (Enem) are boys. However, girls are the majority among the candidates. Data tabulated by the 'State' also shows that the total number of young men do better in the four areas charged by the country's most important assessment. The greatest difference is in Mathematics and Natural Sciences exams (CAFARDO; TOLEDO, 2018, [s.p.]).

Although Brazilian women are the demographic majority in university banks, exact careers such as engineering are still difficult to assess as measures to determine college enrollment or course completion.

Silveira (2011, p. 767) pointed out that Brazil still has the aggravating factor of having its engineering schools developed by the military structure, which could further remove the presence and participation of women: "In Brazil, mathematics courses introduced in military academies were attended at that time only by men; eliciting a masculine construction of the discipline [...]. The discursive formula for mathematics excluded women in military academies."

Lombardi (2005, p. 247) concluded that "the position of women in engineering remains special and exceptional". Despite the greater acceptance of women in schools and in the engineering labor market, the profession has remained dominated by men. From 2001 to 2011, the number of engineering graduates per year increased from 18,000 to 45,000 and female graduates grew from 22 to 24 percent (LOMBARDI; GONZALES, 2016, p. 172). Furthermore, this timid progression of women in the profession did not change patterns of behavior and the coexistence of masculine power in the field (LOMBARDI; GONZALEZ, 2016, p. 173).

Capitalist systems rely on female labor and cannot do without it. Western democratic countries have already removed many legal barriers for women's entry into the workplace, which has elevated women's access to jobs and 
education. With changes in policy, it was expected that there would be an advance in participation over time. However, data shows that, in Brazil, engineering fields will take longer to feminize, especially in contrast with other imperial professions. The reasons for this delay of entry impact sociocultural characteristics of individuals in the profession.

Being a professional in any field involves identifying with the role and related activities and expectations. Professions, mainly prestigious professions, guarantee a high social rank in the hierarchy. The in order for a field, its language, and related knowledge to be legitimized, it is necessary for apprentices to engage professional training, socialization, and effective participation in spaces of the intended profession. According to Lombardi (2017, p. 127):

Built professional identity is a process of socialization that links professional training, work, and careers. Within different companies, institutions, and participation in unions and other collective representation associations, this path will legitimize an individual, attributing he or she professional recognition for themself, the peer community, and society. Far from being static, professional socialization permeates an individuals' life paths, is in constant construction and reformulation, and is subject to broader social, economic, and psychological interferences.

In engineering, professional identity remains linked to prejudice by gender roles, in which characteristics are ranked by power, objectivity, and authority. Characteristics considered feminine including flexibility, delicacy, and fragility, are rejected, which are socialization processes that facilitate the integration of men but hinders opportunities for women to enter the field. Women's lesser presence is also impacted by issues such as income and specific knowledge.

Law no. 4.950-A from 1966 determines an engineer's salary in Brazil (8.5 minimum wages for an eight-hour day). In January of 2018, this represented $\mathrm{R} \$ 8.109 .00$. For example, 
lawyers who earn the state's base salary, earn between $\mathrm{R} \$$ 3.862.50 in the Federal District and R\$ 2.434.79 in Mato Grosso State, Maciente and Araújo (2011, p. 49).

A comparative study about earnings of engineers and other professionals within higher education concluded that: "engineers and related professionals receive salaries systematically above other employees who have achieved higher levels of education." A study in 2017 by Page Personnel about the impacts of the economic crisis of 2015 pointed out that even during difficult times, engineering careers have remained among the highest paid professions:

However, the salary floor for engineers and technicians has shown stability compared to last year. Given the versatility of engineers in Brazil and the scarcity of good profiles among them, there is still heating in the sector. From that, we realized that professionals with more qualifications, even at the beginning of their careers, end up taking the lead (PAGEPERSONELL, 2017, p. 32).

Hence, mathematical knowledge is a source of money and power; gains in engineering careers may not be stratospheric. However, they tend to be higher than other careers in higher education, especially considering training time. Engineers train for about five years and medical professions train between eight and eleven years. ${ }^{6}$

The barrier is not insurmountable because women's participation is slowly expanding. However, the path is hostile and protracted as shown by Andrade (2016) in his consultancy report to the Chamber of Deputies on inequality in the labor market:

The increase in women's participation as a workforce and the arrival of legal, technological, and organizational innovations have not yet brought [sic] a significant change in the functional

$6 \quad$ Medical School has a minimum duration of six years, and the specialization varies between two and five years (SCHEFFER, 2015). 
and technical hierarchy of the labor organization. Because of men's supremacy, most working women are in low-paid activities, without ascending to leadership or management positions (ANDRADE, 2016, p. 35-36).

Being an engineer is still a difficult choice for women. The persistence of a lower presence in engineering exposes the role of sexism and patriarchy in professional choices.

Discussions about how gender inequality is distributed in contemporary relations and states' structures date back to the first half of the 20th century. Decades of reflections, research, and studies analyze gender inequities (SCOTT, 1995). The sexual division of labor is part of the spectrum of pioneering issues in gender debates. We aim to use the engineering landscape by presenting data that compares conditions in Brazil and the United States.

In the first half of the article, we presented data including the number of professionals in engineering careers by men and women, the difficulty of women rising to spaces of power (even in the Academy), and social constructions that inform performance and choice to study mathematics among girls and boys. Using reflections of Maria Rosa Lombardi, who has researched this topic for decades, we seek to discuss and point out possible reasons why women have not yet overcome this mobility barrier in the profession of engineering, which we claim is a symptom of patriarchy and gender discrimination.

A priori, science, technology, engineering, and mathematics (STEM) are areas of relevance for countries, especially developed ones because they cannot progress in the global economy without autonomy in these fields.

The National Science Foundation estimates that about five million people work directly in science, engineering, and technologyjust over 4 percent of the workforce. This relatively small group 
of workers are critical to economic innovation and productivity. Workers in science and engineering fields tend to be well paid and enjoy better job security than other workers (HILL; CORBETT; ROSE, 2010, p. 2).

We seek to explore why fewer women, even today, seek engineering courses, and why boys perform better in core subjects such as mathematics that lead to the study of engineering profession.

Hill, Corbett, and Rose (2010, p. XV) argue that before adulthood, "screening" begins: "One of the largest gender differences in cognitive abilities is found in the area of spatial skills, with boys and men consistently outperforming girls and women. Many people consider spatial skills to be important for success in engineering and other scientific fields. "Since early childhood, toys received, games used to stimulate thinking and behavior, and sports children are enrolled in, children develop and improve skillsets and establish preferences that are inherent to their development. However, there is a division between what is suitable for boys and girls even when it has been exhaustively proven that activities performed by boys and girls are interchangeable.

Structuring of gendered stereotypes begins at an early age. Inaccurate stereotypes permeate about girls and women not being good at mathematics, and there remains the locus of science being better suited to the profile of boys and men rather than women. According to the 2014 City and Guilds Survey of 2000 young professionals, men and women receive different career advice at school. The top three career choices recommended to girls are nursing and care, teaching, and medical fields. For boys, the top there are information technology, engineering, and finance (WES, 2018, p. 5).

It is necessary to recognize the harmful effects of gendered stereotypes. Gender inequality has historically estab- 
lished itself in our societies. As a result of stereotypes, girls and boys have to be reminded that their humanity defines them rather than their sex or gender. Hill, Corbett, and Rose (2010) argue that low performances in mathematics tests among girls and women are influenced by stereotype threat:

A large body of experimental research has found that negative stereotypes affect women's and girls' performance and aspirations in math and science through a phenomenon called "stereotype threat." Even female students who strongly identify with mathwho think that they are good at math and being right in math is essential to them - are susceptible to its effects (Nguyen \& Ryan, 2008). Stereotype threat may help explain the discrepancy between female students' higher grades in math and science and their lower performance on high-stakes tests in these subjects, such as the SAT-math (SAT-M) and AP calculus exam. Additionally, stereotype threat may also help explain why fewer girls than boys express interest in and aspirations for careers in mathematically demanding fields. Girls may attempt to reduce the likelihood that they will be judged through the lens of negative stereotypes by saying they are not interested and by avoiding these fields (HILL; CORBETT; ROSE, 2010, p. 38).

In the 1990s, social psychologist Aronson refined the concept of stereotype threat, corroborating perceptions of developmental progress of boys and limits for girls, which expands the prospects for boys who wish to enter professional engineering and the technology market.

[...] that one reason girls lose confidence as they advance in School stems from "the stereotyping that students are exposed to in School, the media, and even at home that portrays boys as more innately gifted and math as a gift rather than a developed skill. Without denying that biological factors may play a role in some math domains, psychology also plays a significant role (ARONSON apud HILL; CORBETT; ROSE, 2010, p. 41).

Several studies discuss the interrelationship between social relations, stereotypes, and the sexual division of labor. 
[...] The social relations of sex identify a tension that crosses the entire social field, the tension between men and the permanent group of women when it comes to work and its social division. In this sense, the social relations of sex and the sexual division of labor are inseparable. From two organizing principles present in the sexual division of labor, separation, and hierarchy, not only are different jobs assigned to men and women, but jobs are also hierarchical, giving more value to men's work (LOMBARDI'S CONTRIBUTION, 2005, P. 130).

In the armed forces whether in Brazil or the United States, engineering is a genuinely masculine space in the armed forces with practices that are sometimes misogynistic whether in Brazil or the United States. Some were prohibited from entering and pursuing a military career. ${ }^{7}$

[...] modern engineering is born within armies; the discovery of gunpowder and then the progress of artillery, required a complete modification in the fortification works, which, mainly from the 17th century, started to demand qualified professionals for its planning and execution. The need to carry out works that were both solid and economical and roads, bridges, and ports for military purposes, forced the emergence of engineer officers and specialized engineering bodies in armies. This happened in France in 1716, at Vauban's initiative and, in Portugal, in 1763, under the reign of José I, as part of the reorganization of the Portuguese army (SILVA TELLES apud LOMBARDI, 2010, p. 32).

From the 17th century in France until the second decade of the 21st century, the armed forces divisions by army, navy, and aeronautics underwent significant changes. These changes culminated in the authorization for women to join. The first woman to enlist in the Brazilian army was

7 It is worth mentioning, at this point, the women who over the centuries fought for their countries and causes, disguised as men, hiding their feminine condition, or irregularly in guerrillas and resistance movements. Also, women's presence as nurses and later, as doctors, was precious for armies during periods of confrontation. 
Maria Quitéria de Jesus in 1943 during the second world war (MINISTRY OF DEFENSE, online). In the American army, Loretta Wlash enlisted during the World War I in 1917 (US DEPT. OF DEFENSE, 2017, online). Demands to assume command posts and experiences of sexual harassment among peers persisted and gained media attention. However, the recorded advances remain as an example of the hierarchical, bureaucratic structure that is also permeated by concepts and practices forged in the patriarchy and engineering's genesis.

The military characteristic present in the birth of this profession will be associated with it and will last for more than a century in the country, even after the separation of the training of engineers from that given in military schools. The latter prepared officers to continue their military career, and this career, defense, and war affairs have historically constituted themselves as a field of action for men (LOMBARDI, 2010, p. 32).

Between the 1980s and 1990s, a series of transformations in the global economy changed engineering significantly. In Brazil, political changes occurred such as the end of the civil dictatorship and a military established with the 1964 coup and the promulgation of the 1988 Federal Constitution.

For Brazilian engineers, the 1990's began with losses of formal jobs, which reached heightened numbers for men who made up the majority of professionals. Between 1990 and 1998,48247 jobs were lost among engineers in the country, 38576 of which were male and 9671, female (LOMBARDI, 2005 , p. 77). Women were more proportionately affected as this reduction meant a loss of $38.3 \%$ for women and $26.2 \%$ for men (LOMBARDI, 2005, p. 77). Fortunately, formal employment grew again in the early 2000's, and engineers followed the trend and began to show an upward curve.

In addition to the conditions mentioned above, engineering in the 21st century has not progressed to address 
diversity and equity demands either, which also demand solutions to complex problems. As we have seen, gender equity is recognized as necessary to achieve progress in other status areas. In 2019, Richard Miller, president of Franklin W. Olin College of Engineering, stated that "engineering problems for the 21st century are more global, complex, and multidisciplinary. Often, side effects are more significant than the solutions themselves. The new generation of engineers need to be educated to deal with social and cultural changes" (ACADEMIA BRASILEIRA DE CIÊNCIA, 2019, online).

We note that engineering dialogue and nuances of the market and political-bureaucratic organization follow trends of periods of recession and growth, and continue to support a somewhat stagnant reality about the presence and representativeness of women in the field.

There is also a differentiation within engineering where women and men are concentrated. Civil engineering is always the flagship, for men and women. In mechanical and electrical-electronic engineering, men stand out. In contrast, production engineering is a niche where women engineers are found more concentrated (LOMBARDI, 2006):

The gender order, transversal to engineering, classifies/reclassifies and hierarchizes areas of knowledge and areas of work, activities, attributions, and hierarchical positions as more or less masculine or feminine and values them differently. Thus, in terms of the sexual division / redivision of labor, it can be said that the general rules valid for all specialties are as follows: A. the domains of production and factory remain predominantly male; B. in laboratories, not focused on production, women predominate and in those where there are production activities, men; $\mathrm{C}$. Technical assistance activities for companies, consultancies, "relational" activities involving customers, suppliers, employees, seem more permeable to the presence of engineers; $\mathrm{D}$. in senior management and direction positions, there is a tendency for fewer female engineers; E. when 
they assume leadership positions, they seem to focus on specific areas, such as product research and development, marketing .; $\mathrm{F}$. in the direction of the production areas and the management of the factories, there are restrictions on the presence of female engineers, even in industrial sectors where female labor is traditional, such as hygiene and beauty products. In this sense, it can be said that the pattern of insertion of female engineers in the job market is similar to the pattern of all workers, being marked by horizontal (work areas) and vertical (hierarchical rise) segregation (LOMBARDI, 2006a, p. 199-200).

We will not be able to meddle in the purification and understanding of this "internal" differentiation; however, we understand that this scenario dialogues directly with the general panorama applied to engineers as a collective group.

The engineering universe has served as a "showcase" for the permanence in our social fabric of perceptions and certainties that stereotype and stratify men and women. Although Brazil and the United States have overcome many legal barriers of inequality, normative systems struggle to propagate the promise of equality among all. Indistinctly, in the experience of daily life and in the division of domestic labor, we realize that dominant cultural patterns of Western society are active and present. As stated by Bourdieu (1998), societies were built under male domination requiring us to continue moving forward in the perspective of material equality.

The rigidity of these cultural patterns in Western societies has undergone major changes since the 20th century. One of the critical drivers of this transformation was the access of a more significant number of women to secondary and higher education and the opening of their professional options (LOMBARDI, 2005, p. 173).

There is still much to be done regarding the sexual division of labor, especially with regards to decision-making in careers such as engineering. The challenge remains for 
women to overcome these initial resistances mentioned above to opt for engineering. However, throughout their careers, women have migrated to other areas, according to the Society of Women Engineers:

Over $32 \%$ of women switch out of STEM degree programs in college; only $30 \%$ of women who earn bachelor's degrees in engineering are still working in engineering 20 years later; $30 \%$ of women who have left the engineering profession cite organizational climate as the reason (SWE, 2018, online).

Science, technology, and engineering professional aim to reach the largest number of people. The absence of women in product design and solving complex problems has sometimes silenced or put women at risk, which is confirmed by findings in Hill, Corbett, and Rose (2010, p. 3):

[...] some early voice-recognition systems were calibrated to typical male voices. As a result, women's voices were literally unheard of. ... Similar cases are found in many other industries. For instance, a predominantly male group of engineers tailored the first generation of automotive airbags to adult male bodies, resulting in avoidable deaths for women and children" (Margolis \& Fisher, 2002, pp. 2-3). With a more diverse workforce, scientific and technological products, services, and solutions are likely to be better designed and more likely to represent all users.

The Magazine of the Society of Women Engineering, based in the United States, leads discussions, meetings, and publications that aim to contribute effectively to debates, and recognizes the limitations of equity in the field in the 21st century:

The past few years have, in some ways, been discouraging for advocates of gender diversity in engineering. The share of engineering jobs held by women has not increased significantly in the most recent period. One continues to read headlines describing the ongoing controversies over women's experiences in the digital economy. There has also been pushback against efforts to take 
positive steps to increase the numbers of women in engineering and science, with the federal government now joining efforts to eliminate scholarships and other supports that target female recipients. Nevertheless, interest in understanding why there continue to be relatively few women in engineering and what can be done to change that remains Strong (MEIKSINS, et al., 2020, p. 4).

It is necessary to continue building alliances, discussing negative stereotypes, and driving change that explores gender equality as a beneficial movement for society and our countries.

\section{Conclusion}

Analyzing public and private spaces that men and women occupy allows us to reflect upon how social and economic relations are forged. The $21^{\text {st }}$ century has been a scene of civil wars and a pandemic, which have, not without reason, occupied academic reflections and official policies. Still, it is imperative that we not ignore the continuity of structural problems such as gender inequality.

There are several nuances to be addressed. This article described reasons why women are remain as an underrepresented group in engineering, an area of knowledge considered of extreme importance during this century. We believe that when men and women are performing equitably in all relevant modes of decision making including determinants of large budgets, advancements in science, and solutions to current problems, society will be able to advance in material more effectively.

Reasons why low participation rates among women engineers vary, for instance: gaps in socialization processes during adolescent years among girls and boys and stereotypes permeate as a result of perceptions that influence pro- 
fessional choices and performance as adults; fewer girls select engineering career fields and girls who were marginalized are likely to experience stereotype threat, which often interferes with performance even when girls are academically prepared; $30 \%$ of women do not remain in male-gendered careers after the first 20 years. Findings in the literature claim there to be structural problems from childhood to professional life that lend to experiences of gender inequality.

To this extent, we believe that joint efforts between populous countries with significant similarities and differences such as Brazil and the United States can help overcome institutional and civil barriers that maintain glass ceilings.

\section{References}

ACADEMIA BRASILEIRA DE CIÊNCIAS. Uma nova geração de engenheiros focados nos desafios globais do século 21. 2019. Available from: http:/ / www.abc.org.br/2019/08/16/ educando-uma-nova-geracao-de-engenheiros-para-os-desafios-globais-do-seculo-21/. Access on: 25 set. 2020.

ANDRADE, Tania. Mulheres no mercado de trabalho: onde nasce a desigualdade? Consultoria Legislativa. Câmara dos Deputados. Available from: https://www2.camara. leg.br/atividade-legislativa/ estudos-e-notas-tecnicas/ publicacoes-da-consultoria-legislativa/areas-da-conle/ tema7/2016_12416_mulheres-no-mercado-de-trabalho_tania-andrade. Access on: 10 out. 2017.

ANDRADE, Márcia; FRANCO, Creso; CARVALHO, João B. Pitombeira. Gênero e desempenho em matemática ao final do ensino médio: quais as relações. Estudos em Avaliação Educacional, São Paulo, n. 27, jan.-jun. 2003, p. 77-95. 
BRUSCHINI, Maria Cristina Aranha; AMADO, Tina. Estudos sobre mulher e educação: algumas questões sobre o magistério. Cadernos de Pesquisa, n. 64, fev. 1988, p. 4-13.

BRUSCHINI, Cristina; LOMBARDI, Maria Rosa. Instruídas e trabalhadeiras trabalho feminino no final do século XX. Cadernos Pagu, Campinas, n. 17-18, p.157-196, 2002. Available from: <http://www.scielo.br/scielo.php?script=sci_ arttext\&pid=S0104-83332002000100007\&lng=en\&nrm=iso $>$. Access on: 23 Set. 2020.

CAFARDO, Renata; TOLEDO, Luiz Fernando. Homens têm $72 \%$ das mil melhores notas do Enem. Estado de São Paulo, 14 jan. 2018. Available from: https://infograficos.estadao. com.br/educacao/enem/desigualdades-de-genero-e-raca/. Access on: 17 jun. 2018.

CHARLES, Maria; BRADLEY, Karen. Indulging Our Gendered Selves? Sex Segregation by Field of Study in 44 Countries. American Journal of Sociology, v. 114, n. 4, jan. 2009, p. 924-976.

COELHO, Edmundo Campos. As profissões imperiais: Medicina, Engenharia e advocacia no Rio de Janeiro, 1822-1930. Rio de Janeiro: Record, 1999.

CONFEA. Profissionais - Quantidade por gênero. [on-line]. Available from: https://relatorio.confea.org.br/Profissional/ProfissionaisPorGenero. Access on: 28 jan. 2020.

DEPARTAMENTO DE ENGENHARIA DE ENERGIA E AUTOMAÇÃO ELÉTRICAS - ESCOLA POLITÉCNICA. Docentes. Available from: http:/ / www.pea.usp.br/ departamento/docente/. Access on: 19 sep. 2020.

E-GUIA DO ESTUDANTE. Profissões. [on-line]. Available from: https://guiadoestudante.abril.com.br/profissoes/. Access on: 29 jan. 2018. 
HILL, Catherine; CORBETT, Christianne; ROSE, Andresse St. Why So Few? Women in Science, Technology, Engineering, and Mathematics. Washington: AAUW, 2010.

LAYNE, Margaret E. Women in Engineering: pioneers and trailblazers. Reston, VA: American Society of Civil Engineers, 2009.

LOMBARDI, Maria Rosa. Perseverança e resistência: a Engenharia como profissão

feminina. Campinas, 2005. Tese (doutorado). - Faculdade de Educação, Universidade Estadual de Campinas.

LOMBARDI, Maria Rosa. Engenheiras brasileiras: inserção e limites de gênero no campo profissional. Cadernos de Pesquisa, v. 36, n. 127, jan./abr. 2006a, pp. 173-202.

LOMBARDI, Maria Rosa. Engenheira \& Gerente: desafios enfrentados por mulheres em posições de comando na área tecnológica. Revista Tecnologia e Sociedade, v. 2, n. 3, jul.-dez., 2006b, pp. 63-86.

LOMBARDI, Maria Rosa. A Engenharia brasileira contemporânea e a contribuição das mulheres nas mudanças recentes do campo profissional. Tecnologia e Sociedade, v. 2, n. 2, jan.-jun. 2006c, p. 109-131.

LOMBARDI, Maria Rosa; GONZALEZ, Débora de Fina. (2016). Engenharia e gênero: as mutações do último decênio no Brasil. In: ABREU, Alice Rangel de Paiva; HIRATA, Helena; LOMBARDI, Maria Rosa (orgs.). Gênero e trabalho no Brasil e na França: perspectivas interseccionais. São Paulo: Boitempo.

LOMBARDI, Maria Rosa. Engenheiras na construção civil: a feminização possível e a discriminação de gênero. Cad. Pesquisa, São Paulo, v. 47, n. 163, p. 122-146, Mar. 
2017. Available from: <http://www.scielo.br/scielo. php?script=sci_arttext\&pid=S0100-15742017000100122\&ln g=en\&nrm=iso>. Access on: 27 Sept. 2020.

MACHADO, Monica Sapucaia. Direitos das Mulheres: ensino superior, trabalho e autonomia. São Paulo: Almedina, 2019.

MEIKSINS, Peter. Women in Engineering: A Review of the 2019 Literature. Dismantling the Glass Ceiling. Society of Women Engineers. v. 66, n. 2, 2020. Available from: https:// drive.google.com/file/d/1o3onGgEntPvVHjVmhRE59om 1pTkHCGSN/view. Access on: 25 set. 2020.

MINISTÉRIO DA DEFESA. A história da mulher no exército. Available from: http://www.eb.mil.br/ web/ingresso/mulheres-no-exercito/- / asset_ publisher/6ssPDvxqEURl/content/a-historia-da-mulher-no-exercito\#: :text=Maria\%20Quit\%C3\%A9ria \%20de \%20 Jesus \% 20lutou,oficialmente \% 20ingressaram \% 20no \% 20 Ex\%C3\%A9rcito\%20Brasileiro. Access on: 20 set. 2020.

MINISTÉRIO DA EDUCAÇÃO; INEP. Notas Estatísticas: Censo da Educação Superior 2015. 2015. Available from: http://download.inep.gov.br/educacao_superior/censo_superior/documentos/2015/Notas_Estatisticas_Censo_Superior_2015.pdf. Access on: 20 set. 2020.

OLIN COLLEGE OF ENGINEERING. Transforming engineering education. Available from: https://www.olin. edu/research-impact/transforming-education/. Access on: 24 set. 2020.

OLIVEIRA, Maria Fatima; NEGREIROS, João Garrott Marques; NEVES, Ana Cristina. Condicionantes da aprendizagem da matemática: uma revisão sistêmica da literatura. Educ. Pesqui., São Paulo, v. 41, n. 4, dez. 2015, p. 1023-37. Available from: https://www.scielo.br/scielo. 
php?script $=$ sci_arttext\&pid=S1517-97022015000401023\&ln $\mathrm{g}=\mathrm{en} \& \mathrm{nrm}=\mathrm{iso}$. Access on: 31 jan. 2018.

PAGEPERSONELL. Guia de salários: estagiários, analistas e coordenadores 2017- 2018. Available from: https:// www.pagepersonnel.com.br/sites/pagepersonnel.com. br / files / Page \% 20Personnel \% 20-\% 20Guia \% 20de \% 20 Sal \%C3\% A1rios \%20para\%20Estagi\%C3\%A1rios\%2C\%20 Analistas\%20e\%20Coordenadores.pdf . Access on: 18 jun. 2018.

PERUSEK, Anne. Dismantling the Glass Ceiling. Society of Women Engineers. v. 66, n. 2, 2020. Available: https:/ / drive. google.com/file/d/1o3onGgEntPvVHjVmhRE59om1pTkH CGSN/view. Access on: 25 set. 2020.

POLITÉCNICA - ENGENHARIA DE CONSTRUÇÃO CIVIL. Professores. [on-line]. Available from: http://www. pcc.usp.br/o-departamento/pessoal/professores. Access on: 27 sep. 2020.

SCHEFFER, Mário (coord.). Demografia médica no Brasil 2015. São Paulo: Departamento de Medicina Preventiva da Faculdade de Medicina da USP/Conselho Regional de Medicina de São Paulo/Conselho Federal de Medicina, 2015. Available from: http:/ / www.usp.br/agen/wp-content/ uploads/DemografiaMedica30nov2015.pdf. Access on: 27 set. 2020 .

SCOTT, Joan. SCOTT, Joan. El género: uma categoria útil para el análisis histórico. 1996. Available from: https://www. fundacionhenrydunant.org/images/stories/biblioteca/ derechos_economicos_sociales_culturales_genero/El $\% 20$ Genero\%20Una \%20Categoria \% 20Util\% 20para \%20el\% 20 Analisis\%20Historico.pdf. Access on: 08 ago. 2019. 
SILVEIRA, Marisa Rosâni da Silveira. A dificuldade da matemática no dizer do aluno: ressonâncias de sentido de um discurso. Educação \& Realidade, v. 36, n. 3, set.- dez. 2011, p. 761-79.

SOCIETY OF WOMEN ENGINEERS. SWE Research. Available from: https:/ / alltogether.swe.org/wp-content/uploads/2018/09/SWE-Research-Flyer-8_15_18-1.pdf. Access on: 25 set. 2020 .

US DEPARTAMENT OF DEFENSE. Celebrating the First Enlisted Women. May, 2017. Available from: https://www. defense.gov/Explore/News/Article/Article/1127379/celebrating-the-first-enlisted-women/. Access on: 20 set. 2020.

The original research was conceived by Professor Monica Sapucaia Machado in her doctoral research and later reviewed by Professor Denise Almeida de Andrade. The article was designed jointly by the professors. The collection and processing of historical data, primarily contained in point 1, was carried out by Prof. Machado. Professor Chiquita Howard-Bostic carried out the collection and processing of data related to the United States' current scenario, meanwhile the Brazilian authors collected data related to Brazil's. Likewise, Prof. Machado and Prof. Andrade developed the analysis and interpretation of data referring to Brazil and concerning the North American data conducted by Prof. Howard-Bostic. Denise de Andrade drawn the first conclusions, which were revised and amended by Monica Machado and completed by Chiquita Howard-Bostic. (Text provided by the authors) 
Recebido em 07/10/2020

Aprovado em 30/10/2020

Chiquita Howard-Bostic

E-mail: chowardb@shepherd.edu

Denise Almeida de Andrade

E-mail: andradedenise@hotmail.com

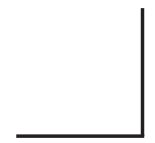

Monica Sapucaia Machado

E-mail:msapucaia@yahoo.com 
